\title{
THE PRESUMPTIVE TAX REGIME ON MICRO, SMALL AND MEDIUM ENTERPRISES IN INDONESIA
}

\section{Chandrika Aditya}

Universitas Indonesia

Email: chandrikaaditya7@gmail.com

\section{Abstract}

In July 2013, Indonesia implemented the presumptive tax regime on micro, small and medium enterprises (MSMEs) by assigning Government Regulation No.46/2013. This regulation simplified the tax administration and provides tax cuts to MSMEs to help them grow and encourage voluntary tax compliance, which eventually will increase their contribution to state revenue. This study provides an analysis of the implementation of this new tax regime by comparing related literature on practices of this tax regime in many countries with the recent conditions in Indonesia after this regulation was applied. It seems that the new tax regime encourages voluntary tax compliance and stimulates the contribution of MSMEs to state revenue. However, some challenges, such as different definitions, lack of tax knowledge, impartiality to business losses, and the indication of tax avoidance must be overcome by the government by improving policies that favor MSMEs.

Keywords: Indonesia, MSMEs, presumptive tax, threshold

\section{Introduction}

Micro, small and medium enterprises (MSMEs) are the backbone of the world economy. In most countries, MSMEs represent more than $90 \%$ of all firms, accounting for a considerable amount of employment and contributing significantly to global and national economic growth (Nasution \& Nanda, 2017). According to data from the Indonesian Central Bureau of Statistics (commonly known as BPS) in 2012, over 56.6 million Indonesian MSMEs contributed 59\% of GDP, employing more than 107 million workers-about $97 \%$ of total employment. Thus, data show that MSMEs have a significant role in the world economy as well as in Indonesia.

As a large and essential part of the economy, MSMEs often face challenges to their growth and viability because they suffer more constraints related to regulation, access to finance, innovation, limited market scale, taxes, and other business skills and practices than large firms (Bank, 2014). Due to these conditions, the number of MSMEs that develop into larger firms is quite limited, which leaves a missing middle, especially in developing countries (Bank, 2014). Therefore, specific policies by the government are urgently needed to help MSMEs survive and grow to contribute more to the economy. 
Tax policy is one of the many policies implemented by governments to help the development of MSMEs. In general, there are two common taxation models for MSMEs: the standard system with a simplified and reduced rate model, and the presumptive model. While the first model only adjusts the general provisions that already exist for application to MSME taxpayers, the presumptive tax model is established with the initial goal of accommodating the special needs of MSME taxpayers, which are certainly different from those of the general taxpayer. Therefore, the presumptive tax model is often applied in developing countries where MSMEs are the majority of business entities and play an important role in the economy.

In July 2013, the Indonesian government introduced the presumptive tax regime to help MSMEs grow and expand and to stimulate their contribution to state revenue. Policymakers issued Government Regulation No.46/2013, 'Final Income Tax on Income from Businesses Received or Obtained by Taxpayers with Certain Turnovers' to encourage the fulfillment of voluntary tax compliance of MSMEs. According to this regulation, MSMEs would be taxed less and more straightforwardly than other common business entities. These special rules were expected to support MSMEs' growth and development and increase their tax contribution to state revenues. However, some weaknesses were found during the implementation of this regulation, which is feared will discourage the development of MSMEs in the future.

\section{Research Method}

This study reviews the implementation of the presumptive tax regime and its impact on MSMEs in Indonesia. In this study, the history of previous tax regulations related to MSMEs in Indonesia is outlined. This study also gives an overview on theories of tax preferences for MSMEs, and also reviews the standard practices in several countries. Furthermore, this study analyses the implementation of the presumptive tax regime on MSMEs by focusing on results and challenges. Finally, it summarizes the findings and provides some conclusions and policy recommendations.

The fundamental problem of small business entities is limited knowledge on the running or expansion of their businesses. In the emerging market, these entities are commonly started by informal, household entrepreneurs and are privately and domestically owned (Mourougane, 2012). Moreover, the biggest challenge for smallscale entrepreneurs is not only access to credit, but also to finding markets (Weber et al., 2018). Therefore, to ensure that small companies make a full contribution to job creation and productivity to support long-term sustainable growth, the government should formulate comprehensive policies which cover all economic aspects of these business entities.

\section{Tax Preference for MSMEs}

Government regulation has a direct effect on the efficiency of the economic activities it regulates. Therefore, in determining policy, policymakers should consider the effect on behaviors as a response to the policy. The role of the law as part of the government policy really determines either the formality or informality 
of a business entity (Marquez, 1990), further explained that a good law would guarantee and encourage economic efficiency, while a bad law would hinder or disrupt it.

A good tax policy for MSME taxpayers should have a positive impact on their voluntary tax compliance behavior and their consideration to become a formal entity. For instance, the proper tax policy could also contribute to the income level of MSME taxpayers by simplifying tax administrations mechanism. With the reduced burden of tax administrations, MSME taxpayers can be more effective and efficient in carrying out their business. On the other hand, excessive tax compliance costs can distort the choice of business entities form, including the decision to transform from dependent employment to setting up a business in incorporated or unincorporated form.

However, there are many benefits of being a formal entity, such as easier banking access or capital inflow for increasing productivity, which can lead to business expansion. In a formal entity, employees' welfare can be improved and become more secure, with the minimum wage set by the government and health and safety guarantees. Therefore, in the context of small business entities, simplifying tax procedures and giving tax incentives make it more attractive for producers to become formal businesses.

There are several options for taxation models for MSMEs, but in general, they can be divided into two major groups (Engelschalk, 2007). (Loeprick, 2009). the standard regime system and the presumptive regime system. According to the standard regime, MSMEs are not treated differently in taxes than any other entities. However, there are some countries that apply the standard regime with some adjustment for small taxpayers by simplifying their tax forms, payment procedures, or tax rate reduction. Countries that implement the standard scheme for MSMEs, in general, are mostly developed, with MSME communities that have high administrative efficiency and adequate bookkeeping capabilities (Loeprick, 2009).

In the presumptive regime model, tax is imposed based on the presumption of specific conditions of the taxpayer (Thuronyi, 1996). The presumptive regime is mainly used in countries where most of the taxpayers are hard to tax, and with insufficient administrative resources. In those countries, most taxpayers do not have financial transparency that allows for effective taxation by the government. Therefore, the government needs to make estimates or presumptions on the appropriate income to be taxed. Commonly, the presumptive regime is more widely applied in countries which have taxpayers with inadequate accounting skills. This regime is used to increase tax compliance and encourage taxpayer's bookkeeping records.

The application of the presumptive regime generally uses turnover-based systems, indicator-based systems, or a combination of both (Engelschalk, 2007) and (Loeprick, 2009). The turnover-based system begins by assuming that most companies monitor their money receipts and observe them directly, whereas the 
indicator-based system used specific indicators, such as floor area, number of workers, or electricity usage. Another option for estimating taxable income from small businesses is by their cash flow, which is defined as the net amount of cash and cash-equivalents being transferred into and out of business that represents operating activities. However, the cash flow system needs more recordkeeping requirements than the turnover system, but is more suitable for graduating companies to the standard system. In many OECD countries, the presumptive regime with the turnover-based system is a commonly used model for MSMEs (Clarke \& Lee, 2018). Another advantage of using a turnover-based system is that turnover can be taxed directly at a low rate or utilized to determine the income that can be assessed based on factors that are close to profitability.

Since the main reason for implementing the presumptive regime is to reduce time and costs of compliance, a single rate is generally chosen to simplify the mechanism and tax administration (Engelschalk, 2007) and (Loeprick, 2009). However, the arrangement of the single rate for MSMEs should consider the specific characteristics of MSMEs that have been adjusted for their financial ability. The single tax rate must be a rate that reflects policymakers' preferences for the principle of equity and fairness. This principle is needed to ensure that the predetermined tax rates will not create excessive burdens of MSMEs yet ensure business continuity and stimulate the development of MSMEs.

The general purpose of small business tax reform is to build a culture of compliance by simplifying tax administration for MSMEs. The key success of this concept is based on the presumption of the taxpayers' awareness to report their tax truthfully. With limited resources and capabilities, complicated tax rules will prevent MSMEs from fulfilling their tax obligations. Using turnover as the base indicator, and implementing a single rate will save time and cost of compliance. Simple tax rules are easier for taxpayers to understand and encourage them to report their taxes correctly. Some studies show that better tax knowledge increases taxpayer compliance (Inasius, 2015), (Kirchler \& Maciejovsky, 2001), (Park \& Hyun, 2003).

Reducing the tax compliance burden of MSME taxpayers may require cutting the complexity of different tax laws or introducing some simplifications of tax administration. Further requirements may be to ensure that more formal regulations, such as the filing procedures, recordkeeping requirements, procedures for appeal or payment delays, are not unnecessarily complicated. An effective tax system for MSMEs is a system in which policies, legislation, compliance strategies and taxpayer services are carefully aligned (Mourougane, 2012). Such a system is the most likely to reduce compliance burdens for MSMEs, promote MSMEs compliance and lower costs for the tax administration.

\section{Common Challenges}

The presumptive regime exchanges fairness and equality with simplicity, which can cause distortions into the system. The indicators used are usually rough 
proxies for business profitability. Turnover-based taxation systems are cruel for firms which have low profit margins and are generous for those which have high profit margins. Besides, this regulation will be considered discriminatory for taxpayers outside the system. Special simplified regimes for small firms, on the other hand, are commonly used and frequently recommended to promote compliance. Many developing countries already use some presumptive tax systems for small contributors, but results are varied because the main challenge in most (Loeprick, 2009).

Policymakers should also be concerned about the risk of abuse that comes from the difference in treatment of MSME taxpayers to any other common taxpayers. Numerous studies have been conducted to assess that risk. Research by (Bruhn \& Loeprick, 2014). found some indications of reducing tax compliance in a given year around the turnover threshold for the presumptive tax regime by Georgian companies during 2011-2014. Nevertheless, no evidence was found of significant strategic sorting around the feasibility threshold for the new tax regime (Bruhn \& Loeprick, 2014).

A further study by (Engelschalk \& Loeprick, 2015) using broader coverage of countries in the European and Central Asian regions has provided more significant results. The adoption of a new tax regime indicates the potential benefits by reducing compliance costs and encouraging higher levels of participation. The results also show that a poorly designed small entities tax system in the region becomes an obstacle for small entities to increase their turnover above the threshold, which creates an obstacle to migrate upward out of the system. This phenomenon distorts business development and thus fundamentally contradicts the purpose of the presumptive tax regime practice. This research on transition economies is relevant for Indonesia as one of the emerging economies, although with a different type of economy.

Therefore, the government should monitor the implementation of the presumptive tax regime. Comprehensive supervision, followed by tax audits for taxpayers who are signalled as committing fraud, can ensure that this policy is implemented properly. Several kinds of research have shown that the implementation of tax audits can improve taxpayer compliance and has a positive effect in preventing tax avoidance efforts (Niu, 2011), (Santoro, 2017), (D'Agosto, Manzo, Pisani, \& D'Arcangelo, 2018). However, the large number of MSME taxpayers which have different characteristics from the general taxpayers requires the tax authorities to adopt a special approach in conducting audits of MSME taxpayers. Tax auditors can focus on monitoring specific taxpayers whose turnover is close to the threshold which indicates attempts to avoid tax.

3. Concluding Comments

Much research has been conducted on the taxation of MSMEs in Indonesia. From the data survey of small business taxpayers in Jakarta, Inasuis (2015) examined factors influencing MSMEs' tax compliance. However, this research did 
not focus on the impact of the implementation of the new tax regime on MSMEs. A study by (Purwaningsih, 2014) about the impact of Government Regulation No.46/2013 only simulated the different calculations of tax revenue between the new tax regime and the previous tax regime, and did not present the real MSME taxpayers' data.

Further, several studies limited their focus on the implementation of the new tax regime on MSMEs to specific areas in Indonesia. For example, (Iswoyo, Ermawati, \& Alfi, n.d.) reviewed the implementation of Government Regulation No.46/2013 for MSMEs in Surabaya, East Java. It was found that the new tax regime did not have a positive impact on tax revenue in the region. However, the general conditions were not described. The empirical study by (Dunggio, Elim, \& Mawikere, 2017) revealed the decline in the number of taxpayers and the slight increase in tax revenue after the implementation of the new tax regime in Luwuk, Central Sulawesi.

Research on the implementation of the presumptive tax regime on MSMEs in some countries indicates the potential benefits by reducing compliance costs that encourage the higher levels of tax participation. While some previous research in Indonesia specifically limited the scope of discussion on the implementation of the presumptive tax regime in certain regions, or merely conducted a simulated comparison with the previous regulation. There is no case study that analyses the implementation of the presumptive tax regime on MSMEs for Indonesia overall.

Which tax regime should be chosen that is more relevant for Indonesia, by considering its effect on the behavior of MSMEs? Has the implementation of the presumption tax model been successful and give a positive contribution to the formality and tax revenue increment? Has Indonesia overcome the challenges? These questions have not yet been answered in the literature. Therefore, this study is expected to fill this gap by reviewing the implementation of the presumptive tax regime on MSMEs, focusing on the effect of voluntary compliance and tax revenue that will be discussed in the next section.

\section{Result and Discussion}

In July 2013, the Indonesian government implemented Government Regulation Number 46 of 2013 to encourage voluntary tax compliance and enhance the contribution to state revenues from MSMEs. This regulation imposed a final income tax on income received or obtained by taxpayers with certain turnover limits. According to this regulation, taxpayers with a gross turnover not exceeding IDR 4.8 billion in one taxation year will be taxed at a $1 \%$ rate of final income tax from their monthly turnover. This ease of reporting and payment administration can reduce the cost of compliance and can also increase the voluntary compliance of taxpayers. In general, the difference between a standard system and the presumptive model can be seen in Figure 1. The following subsections discuss the elements of the taxation system shown in the figure. 


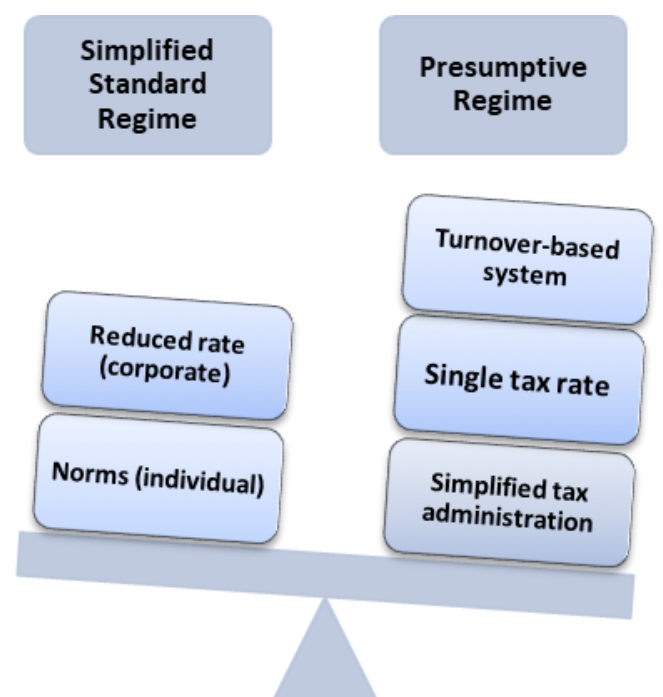

Figure 1.

Taxation System for MSMEs (Author, 2019)

\section{Turnover-based System}

In the presumptive regime, determining the boundaries of taxpayers who are entitled to facilities for simplicity and convenience is crucial. Even though the Income Tax Law did not explicitly state the limitations of MSMEs, the gross turnover limit of IDR 4.8 billion was already in use to limit individual taxpayers who obtain waivers by using Net Income Calculation Norms to calculate their taxable income. This limit was also used for taxpayers who obtain waivers under the Value Added Tax law which has been implemented in Indonesia since 2009. Therefore, the gross circulation limit of IDR 4.8 billion can be used as a criterion for MSMEs, which need an easy and simple taxation system.

However, defining MSMEs according to the criterion of the limit of IDR 4.8 billion for taxation purposes does not match the definitions used by other agencies. The different definitions used for MSMEs reveal the lack of coordination between government agencies, which raises various obstacles in determining policy. Tax policy, according to Government Regulation No.46/2013, will not be applicable to all MSMEs as mandated by the MSME Law, since the benchmarks used are different. Also, the non-uniformity of MSMEs criteria creates difficulties for the government to integrate tax policy with other policies to support the growth and development of MSMEs in Indonesia. Therefore, the government should harmonize the definition of MSMEs and also build better coordination between agencies before establishing further policies.

Compared with a standard system that uses taxable income as a tax base, the presumptive tax model uses turnover as a tax base, which, however, will produce challenges for MSMEs. Since the monthly turnover is used as a tax base rather than the taxable income, taxpayers who incur losses will suffer more since they still have to pay taxes. One of the main objectives of the implementation of the new tax regime is to enhance the number of MSME taxpayers. Taxing MSMEs who suffer 
losses will certainly be very burdensome and counterproductive to the original goal of the new tax regime.

\section{Single Tax Rate}

The equity and fairness principles should be considered when assigning an exact tax rate for MSME taxpayers. An excessively high rate compared with the regular rate in the standard regime will create a disincentive to fulfilling tax obligations. However, rates that are too low will create a moral hazard for general taxpayers other than MSMEs and encourage them to obtain benefits by positioning themselves as MSMEs. Therefore, consideration of the distribution of MSME profit margins is necessary for setting an effective rate.

As shown in Figure 2, the distribution of profit margins for the majority of micro and small-sized enterprises indicates a profit margin of above $10 \%$, while the majority of medium-sized business profit margins are below $10 \%$.

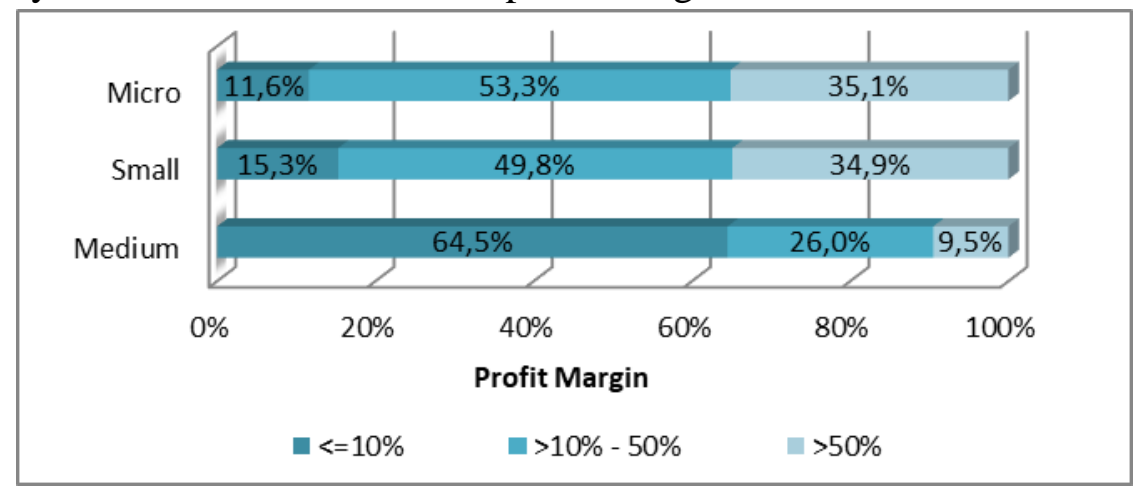

Figure 2.

MSMEs' Profit Margins (BPS, 2012)

A similar result, as demonstrated in Figure 3, was obtained from the intersectoral MSME profit margin data for each business group. Hence, the determination of the tax rate by assuming a profit margin below $10 \%$ is considered not to have a negative effect, since the distribution of micro and small business profit margins is above $10 \%$. However, for medium-sized businesses, determination of the tax rate with an assumption of below $10 \%$ profit margin is correct, as the data on the distribution of the majority of medium business profit margins is below $10 \%$. Therefore, determining the effective single rate of final income tax below $10 \%$ for all business groups is appropriate because micro and small business groups will gain incentives, while medium enterprises will not be affected significantly. 


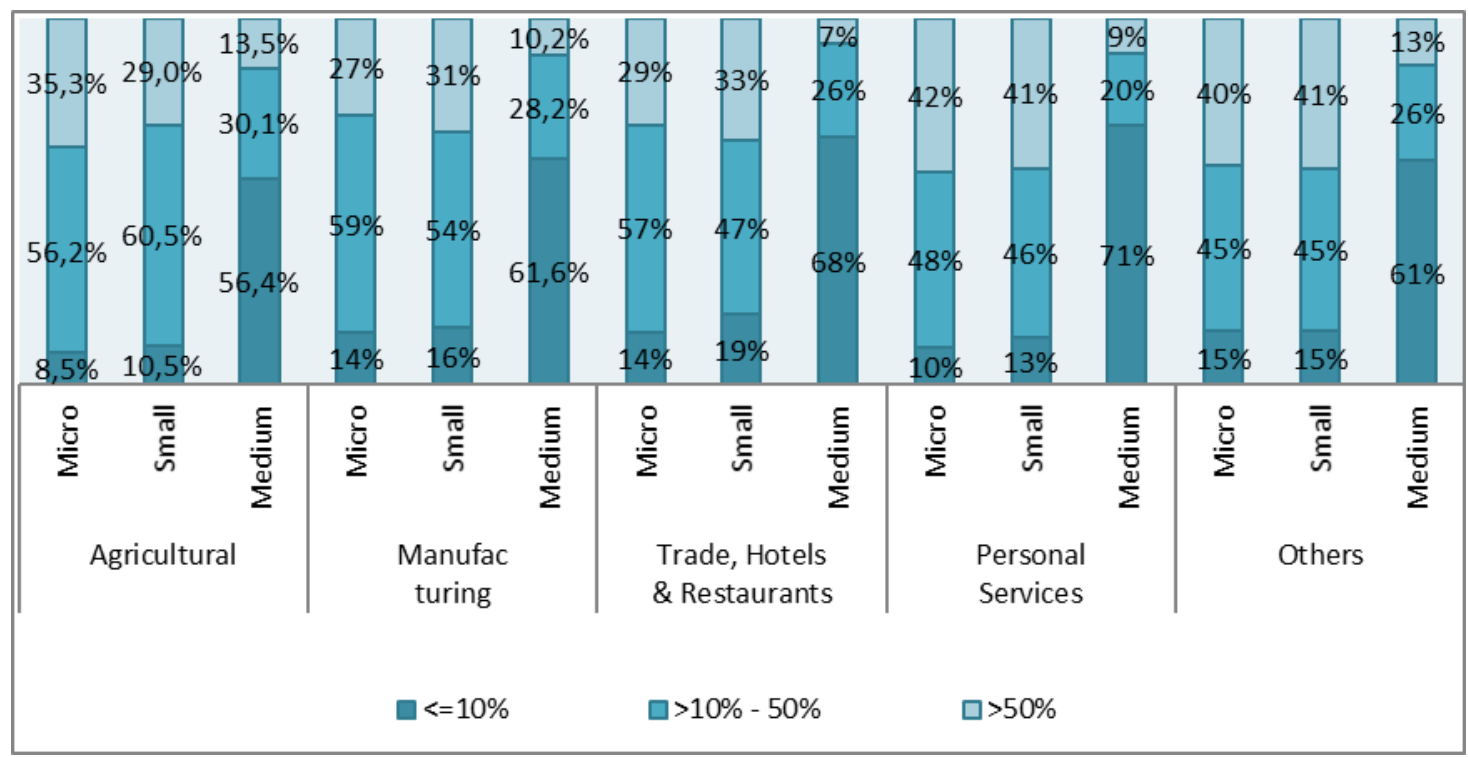

Figure 3.

Inter-sectoral MSMEs' Profit Margins (BPS, 2012)

Nevertheless, the government needs to consider some challenges that possibly arise following the implementation of the single tax rate. The significant reduction in tax rates for MSME taxpayers is suspected of decreasing tax revenues in general. Thus, the government should take into accounts the possible shortfall of tax revenue after the new tax regime is implemented. In addition, the difference in treatment by the significant reduction in tax rates for MSMEs compared to other common taxpayers will create the risk of abuse which might produce a decline in the level of compliance of non-MSME taxpayers. The effects on non-MSME taxpayers need further research beyond the discussion in this study.

\section{Simplified Tax Administration}

According to Government Regulation No.46/2013, various facilities in calculating and paying taxes are provided to the MSME taxpayers. They only need to pay taxes of $1 \%$ from their monthly gross turnover. Taxpayers also do not need to report their monthly tax notice, as previously required, because their payment has already been recorded in the central tax system. Even though they still have to report the annual tax notice, the mechanism is much simpler than the general rule. Since the $1 \%$ tax is final, the total annual gross turnover would not be recalculated in the usual income tax calculation scheme but will only be reported in the attachment section of the tax notice. Various procedure simplifications and all the facilities provided to MSME taxpayers are expected to stimulate their voluntary compliance with their tax obligations properly.

\section{Results}

The implementation of the new tax regime has a positive impact on the involvement of MSME taxpayers in taxation. Based on the data of registered MSME taxpayers shown in Figure 4, the number of registered MSME taxpayers increased significantly, especially the individual taxpayer, while corporate taxpayers increased only slightly. It means that simplicity and tax cut has 
successfully encouraged formality among small business entities along with the growth of their voluntary tax compliance.

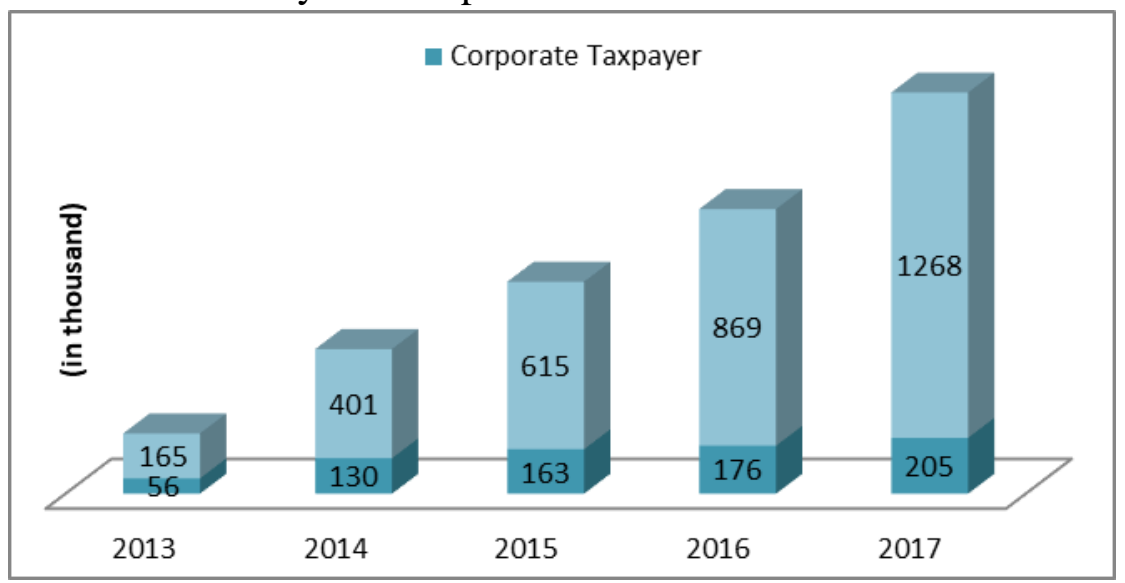

Figure 4.

Registered MSME Taxpayers (Ministry of Finance, 2018)

Meanwhile, tax revenue data gathered since the new tax regime implemented in July 2013 can be seen in Figure 5. Although there is a concern that the impact of the tax cut will be a decrease in revenue, the tax revenue of the MSME taxpayers has continued to increase. It means that the growth of voluntary tax compliance has a positive effect on tax revenue. The reason the tax revenue shortfall did not occur is that there was a significant addition of the tax base of registered MSMEs.

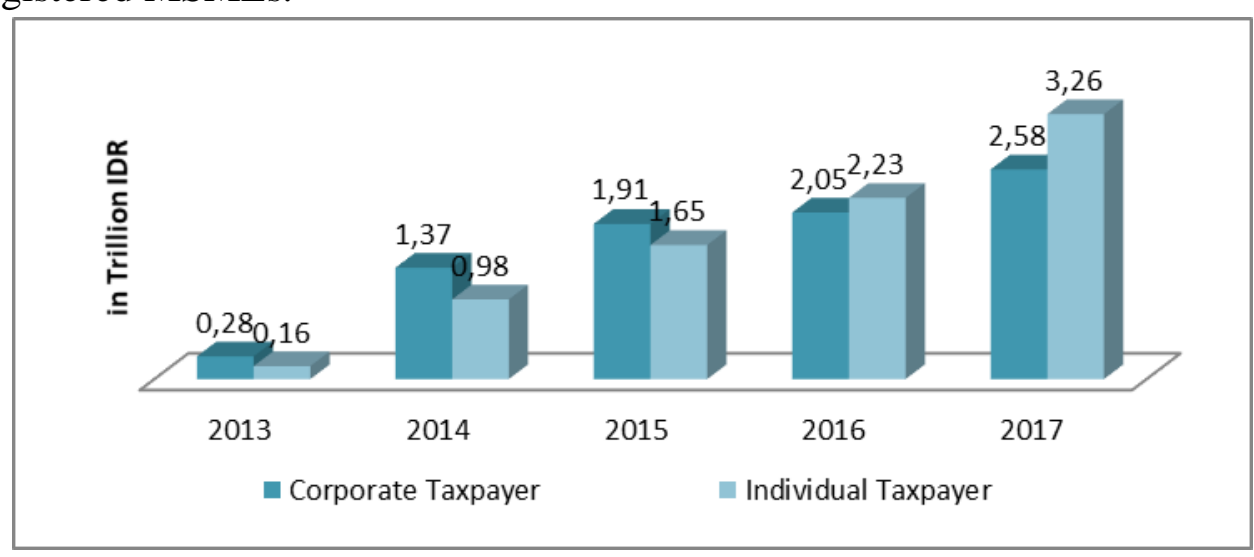

Figure 5.

Tax Revenue of MSMEs (Ministry of Finance, 2018 - start from July 2013)

The crucial issue in this study is the establishment of the turnover threshold. As mentioned in the literature review, the turnover threshold is suspected of a disincentive for small businesses to grow, thus becoming an obstacle to migration upward out of the system. However, according to the data in Figure 6, those suspicions are hard to prove. Figure 6 shows the composition of MSME taxpayers according to their reported turnover for each taxation year under the new tax regime. No significant numbers of MSMEs taxpayers stay below, or even close to the threshold limit of IDR 4.8 billion. 


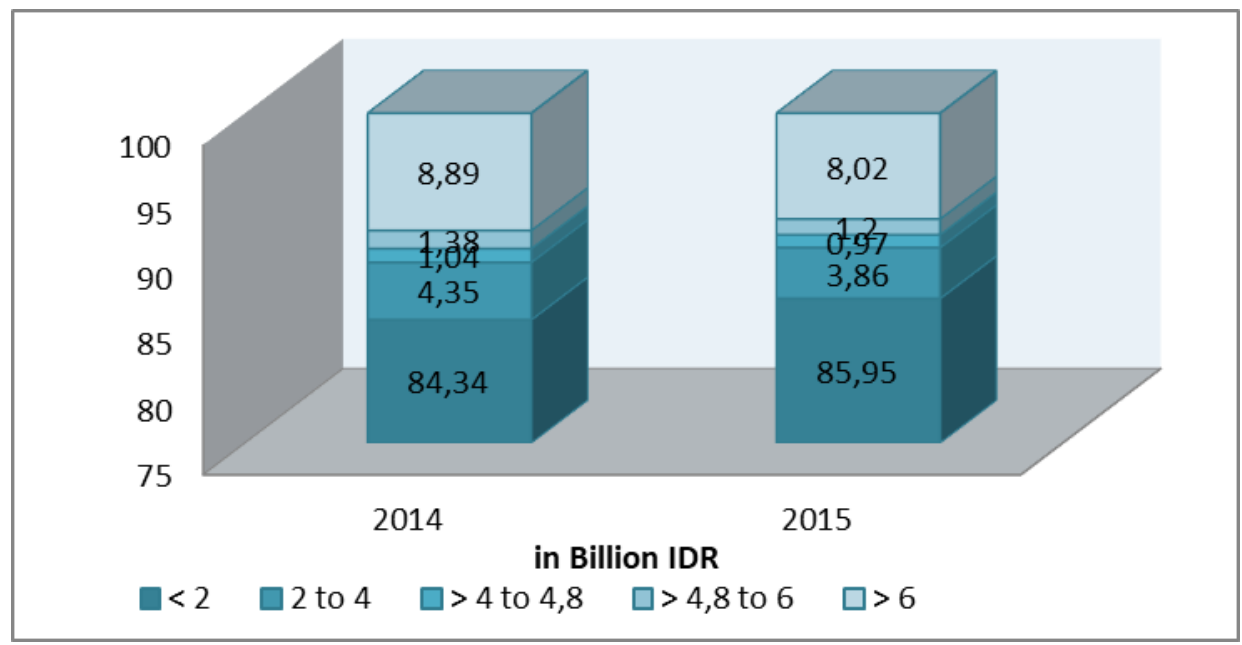

Figure 6.

Composition of MSME Taxpayers according to The Turnover (DGT, 2018)

However, there are some taxpayers who have already risen above the turnover threshold but keep using the tax cut facilities. This is possible as the Government Regulation No.46/2013 allows MSME taxpayers to still use a 1\% tax rate until the end of taxation year although their turnover has exceeded the limit of IDR 4.8 billion during the year. However, the number of taxpayers who should use normal rates but still use tax cut facilities is significant, which can be an early indication of tax avoidance. Therefore, tax authorities need to supervise taxpayers more thoroughly, especially those with a turnover close to the threshold.

\section{Challenges}

The implementation of the new tax regime on MSMEs is not without constraints. The many different definitions of MSMEs expose a lack of coordination between stakeholders and constitutes an institutional challenge which creates difficulties for intra-government agencies to establish comprehensive policies. Therefore, a formulation of the best single definition of MSMEs that can be applied across the economy is urgently required.

A large number of MSME taxpayers whose understanding of tax rules is relatively poor makes it very difficult for tax authorities to conduct supervisions and audits more comprehensively. A lack of tax knowledge, combined with a lack of supervision, tends to encourage taxpayers to act fraudulently by reporting the turnover incorrectly in an effort to evade tax. Also, the significant tax cut compared with the common tax rates for other taxpayers will encourage MSME taxpayers to keep their turnover below the threshold in order to be able to take advantage of tax facilities.

\section{Conclusions}

In summary, the presumptive tax regime for MSMEs in Indonesia is likely to yield the best results, provided that several problems are resolved. This new tax regime can encourage voluntary tax compliance and also stimulate their contribution to state revenue. By simplifying the tax administration mechanism, the cost of compliance can 
be reduced. The voluntary compliance of MSME taxpayers has also been stimulated by the lower tax rate granted by policymakers as evidenced by the increased number of registered MSME taxpayers and the amount of tax deposit after the Government Regulation No.46/2013 was enacted.

However, the implementation of the new tax regime for MSMEs still leaves several problems. Many different definitions of MSMEs create difficulties for intragovernment agencies to establish comprehensive policies. In addition, MSMEs' lack of tax knowledge obstructs the tax policy from achieving optimal results. The use of turnover as a tax base seems cruel for taxpayers who suffer losses from their business. Moreover, the existence of a significant number of taxpayers who still use tax cut facilities when their turnover already exceeds the threshold can be an early indication of tax avoidance. All of these challenges oblige the government to formulate further policy decisions. 


\section{REFERENCES}

Bank, W. (2014). Global financial development report 2014: Financial inclusion. World Bank Washington, DC.

Bruhn, M., \& Loeprick, J. (2014). Small Business Tax Policy, Informality, and Tax Evasion-Evidence from Georgia. The World Bank.

Clarke, T., \& Lee, K. (2018). Introduction: Fast Cycle Innovation in the Asia Pacific. In Innovation in the Asia Pacific (pp. 1-42). Springer.

D’Agosto, E., Manzo, M., Pisani, S., \& D’Arcangelo, F. M. (2018). The Effect of Audit Activity on Tax Declaration: Evidence on Small Businesses in Italy. Public Finance Review, 46(1), 29-57.

Dunggio, J. A., Elim, I., \& Mawikere, L. (2017). Analisis Penerapan Peraturan Pemerintah Nomor 46 Tahun 2013 Terhadap Pertumbuhan Jumlah Wajib Pajak Dan Penerimaan Pph Pasal 4 Ayat (2). Going Concern: Jurnal Riset Akuntansi, 12(2).

Engelschalk, M. (2007). Designing a tax system for micro and small businesses: guide for practitioners.

Engelschalk, M., \& Loeprick, J. (2015). MSME taxation in transition economies: country experience on the costs and benefits of introducing special tax regimes. The World Bank.

Inasius, F. (2015). Tax compliance of small and medium enterprises: Evidence from Indonesia. Accounting \& Taxation, 7(1), 67-73.

Iswoyo, A., Ermawati, Y. N., \& Alfi, W. R. (n.d.). Review of the Implementation of Government Regulation No. 46 Year 2013: Contributions and Constraint for SMEs. Proceeding of International Conference on Economics, Business and Social Sciences (ICEBUSS).

Kirchler, E., \& Maciejovsky, B. (2001). Tax compliance within the context of gain and loss situations, expected and current asset position, and profession. Journal of Economic Psychology, 22(2), 173-194.

Loeprick, J. (2009). Small business taxation: Reform to encourage formality and firm growth.

Marquez, A. (1990). The Other Path by Hernando De Soto. Boston College Third World Law Journal, 10(1), 204.

Mourougane, A. (2012). Promoting SME development in Indonesia.

Nasution, N. H., \& Nanda, S. T. (2017). Pengaruh Pendapatan Premi, Hasil Underwriting, Hasil Investasi Dan Risk Based Capital Terhadap Laba Perusahaan 
The Presumptive Tax Regime on Micro, Small and Medium Enterprises

Asuransi Umum Syariah.

Niu, Y. (2011). Tax audit impact on voluntary compliance. Journal of Economic and Social Measurement, 36(4), 237-251.

Park, C.-G., \& Hyun, J. K. (2003). Examining the determinants of tax compliance by experimental data: A case of Korea. Journal of Policy Modeling, 25(8), 673-684.

Purwaningsih, A. (2014). Impact of Government Regulation No. 46 Year 2013 in Income Tax of Small and Medium Enterprises in Indonesia. Review of Integrative Business and Economics Research, 3(2), 52.

Santoro, A. (2017). Do Small Businesses Respond to a Change in Tax Audit Rules? Evidence from Italy. Public Finance Review, 45(6), 792-814.

Thuronyi, M. V. (1996). Tax law design and drafting (Vol. 1). International Monetary Fund.

Weber, R. J., Van Den Brink, J. C., Turner, K. J., Moes, B. C., Kuyvenhoven, N. W., Eurich, S. T., ... Johnson, C. E. (2018, January 16). Variable mode wireless power supply systems. Google Patents. 